\title{
Marketing Mix Factors that Influence Visitors Choose Aeon Mall as a Shopping Tourism Destination
}

\author{
Cathy Naftali ${ }^{*}$, Adinoto Nursiana ${ }^{2}$, Himawan Brahmantyo ${ }^{3}$ \\ 1,3 Sekolah Tinggi Pariwisata Trisakti \\ 2Sekolah Tinggi Ilmu Ekonomi Wiyatamandala \\ *cathnaftali@gmail.com
}

\begin{abstract}
Aeon mall is company from Japan, and joint venture with Sinarmas Land for PT.AMSL Indonesia. Aeon mall grand opening in BSD, Tangerang 30 May 2015, after two years from the opening Aeon Mall has already many visitors from area in Jabodetabek. Marketing mix approach is used from Morrison (2002) product, price, place, promotion, people, packaging and programming, also partnership. The aim of this study was to determine the effect of marketing mix based on Morrison theories to visitor decision of visiting Aeon Mall. This research used descriptive method approach. The population in this study is Aeon Mall visitors. The respondent was chosen by random sampling. The numbers of respondents are 218 people. The data was collected by distributing questionnaires. The analysis technique used validity and reliability, frequencies, mean, the classical assumption test, t-test, f-test, regression analysis, hypothesis test and coefficient of determination by using SPSS for windows 20.0. The study found that there was a positive and significant impact of product, promotion, and partnership to visitor's decision of visiting Aeon Mall. But there wasn't a positive and significant effect of price, place, people, packaging and programing to the visitor's decision of visiting Aeon Mall.
\end{abstract}

Keywords: marketing mix, product, price, place, promotion, people, packaging and programming, partnership, visitors decision 


\section{A. Introduction}

Aeon Mall is the first Japanese mall that is built in Indonesia. It's established on 30 May 2015, located in BSD, South Tangerang. Aeon Mall is in cooperation with Sinar Mas Land and joint venture of PT.AMSL Indonesia for the development of shopping areas. In Indonesia, Aeon open branches in 12 Asian countries, such as Malaysia, Philippines, India, Hong Kong, and others.

Mall on 20,000 hectares of land, Aeon Mall has 280 stores, including 47 stores from Japan, and 25 of them newly opened in Indonesia, and there are 2.000 parking capacities. There are lifestyle functions as a hangout, meeting point, and entertainment places.

Shopping malls are a familiar term nowadays "shopping center as a retail property that is planned, built, owned and managed as a single entity comprising commercial rental units (CRU) and common areas, with a minimum size of 10,000 square feet (Gross leasable area or GRA) and a minimum of three CRUs. On-site parking is also common provided "(International Council of Shopping Center: 1999).

Activities made by the visitors in the shopping center is vary, such as go shopping, go watching, hang out with friends, walk around the mall, enjoy food.

Nowadays shopping center has become a life style for urban people. Shopping centers are not just for shopping but many people are doing important meetings in shopping centers.

In order to succeed well, Aeon Mall develop strong and integrated effort of implementing aspects of product, price, place, promotion, people, packaging programming, and partnership. Marketing mix strategy covers all of these aspects, so the application of a marketing strategy will impact on the success of tourism object development.

\section{B. Literature Review}

Marketing mix can be defined as the strategy to control and use marketing tools that the company respons the target market behavior. The marketing mix consist of the number of effort to influence the demand for its product (Kotler, 2010:70).

Morrison (2002: 21) states that marketing strategy is the 8 P's of marketing. They are product, price, place, and promotion, people, packaging, programming, and partnership.

\section{Product}

A product any effort that is given to the market in order to satisfy the customer needs by attract the attention the customer to buy, consume, or use (Kotler, 2010:230).

Products in hospitality and travel consists of (1) Staff behavior, appearance, and uniform, (2) Building exterior, (3) Equipment, (4) Furniture and 
fixtures, (5) Signage, and (6) ) Communications among customers and other publics.

\section{Price}

Price is the amount of money that must be paid to obtain the product (Kotler, 2010:70). Price is the amount of money that is charged for a goods or services. More broadly, price is the sum of the value of consumers exchanges for benefits of having or using the product or service (Kotler, 2010:291).

\section{Promotion}

Promotion is an element of marketing mix to inform, persuade and remind the market of a product and/or the organization. The objective is to influence beliefs or behavior of the recipients (Stanton, 1994:456).

\section{Place}

There are two distribution concepts. They are direct distribution and indirect distribution. Direct distribution occurs when an organization takes on overall responsibility for promotion, serving, and providing services to customers / travelers. For example some packages that can only booking directly to the organization itself. While indirect distribution occurs when some responsibility and promotion, ordering of service provision is given to one or more of the other hospitality and travel organizations (Morisson, 2002: 339).

\section{Packaging and Programming}

Hospitality and travel services are perishable. The sales without an excellent packaging and programming will be failled. Packaging and techniques related to programming play a very important role in the sale of services when the demand for such services is very low.

Package is a combination of related and complementary services by offering a single price. This means that in a certain price already includes several types of related services. Program is a technique that closely related to the packaging. It includes the development of special activities, events, or programs aimed at increasing tourist spending (Morrison, 2002: 314).

Packaging and programming are related concepts. Some packages include some programming, and often those programs as a driver of the demand for those special packages. But it is also possible to create packages without programs such as room rate packages including breakfast, or otherwise unlimited programming like Monday night, and early bird discounts do not have to be customized.

\section{Partnership}

Partnership is a collaborative effort in promotion and other marketing cooperation from hospitality and travel organization. These efforts are from "one short" or short-term cooperation in promotion to long-term marketing 
agreements in marketing that may involve multiple combinations of products or services and two or more organizations.

\section{People}

People are an essential element in the production and delivery of services. The quality of the service is largely determined by the quality and behavior of the company's staff. This is particularly true in respect of those whose jobs involve high levels of customer contact (McDonald, Frow and Payne, 2011:37).

\section{Buying Decision}

Buyer decision process consists of five stages: need recognition, information search, evaluation of alternatives, purchase decision, and post purchase behavior (Kotler (2010:164).

\section{Mall}

A shopping Mall or shopping Centre is a building or set of buildings which contain retail units, with interconnecting walkways enabling visitors to easily walk from unit to unit (Pacione, 2005).

A shopping mall is an enclosed shopping center that have large structure managed by a single company housing a variety of retail shops and services, surrounded by a parking area, and situated in a suburban setting; or any large shopping center; or a mixed used shopping complex, which combines stores, services, offices, restaurants, recreations, and other functions (Shopping Mall and Shopping Center Studies: Eastern Connecticut State University,2009).

\section{Research Methodology}

The number of samples is determined by using Hair et al (2006) as follows: $\mathrm{n}=\mathrm{q} \times 5 . \mathrm{n} \quad$ is sample population; $\mathrm{q}$ is research variable; 5 is number of observers with Hair Theory. Based on the formula can be calculated sample taken from this research is 185 but the numbers of respondents in this study are 218 people. The research sampling technique was convinience sampling. The questionnaires were distributed in February to May 2017. The data was collected by distributing questionnaire to respondents.

This study used descriptive methods approach. The test consisted of validity, reliability, frequencies, mean, t-test, f-test, classical assumption test, hypothesis testing, and coefficient of determination. They were analyzed by using SPSS 20.

\section{Result and Discussion}

\section{Validity and Reliability}

The result of validity and reliability test can be describes in Table 1. According to the data result all statements in the questionnaires are valid and reliable. 
Marketing Mix Factors that Influence Visitors Choose Aeon Mall as a Shoping Tourism Destination

Table 1. Results of Validity and Reliability Test

\begin{tabular}{|c|c|c|c|c|}
\hline No & Indicator & $\begin{array}{l}\text { Factor } \\
\text { Leading }\end{array}$ & $\begin{array}{l}\text { Cronbach's } \\
\text { Alpha }\end{array}$ & Status \\
\hline & Product & & 0.856 & Reliable \\
\hline 1 & Customers enjoy a wide range of shopping activities. & 0.771 & & Valid \\
\hline 2 & The Mall building is clean and well maintained. & 0.553 & & Valid \\
\hline 3 & Aeon Mall exterior and interior design are attractive. & 0.555 & & Valid \\
\hline 4 & Aeon Mall has adequate parking facilities. & 0.816 & & Valid \\
\hline 5 & Aeon Mall has clean toilets. & 0.726 & & Valid \\
\hline 6 & Aeon Mall has good information service. & 0.501 & & Valid \\
\hline 7 & $\begin{array}{l}\text { Aeon Mall provides a comfortable and quiet environment } \\
\text { for visitors. }\end{array}$ & 0.448 & & Valid \\
\hline \multirow[t]{2}{*}{8} & Aeon Mall has a favorable security condition for visitors, & 0.455 & & Valid \\
\hline & Price & & 0.649 & Reliable \\
\hline 1 & Aeon Mall has affordable parking rates. & 0.511 & & Valid \\
\hline \multirow[t]{2}{*}{2} & The prices of goods match to its quality. & 0.511 & & Valid \\
\hline & Place & & 0.921 & Reliable \\
\hline 1 & Aeon Mall is located close to the main road & 0.732 & & Valid \\
\hline 2 & Aeon Mall is located in an area that is easy to access. & 0.874 & & Valid \\
\hline 3 & Local transportation is available. & 0.875 & & Valid \\
\hline 4 & Aeon Mall is close to other tourism destination. & 0.804 & & Valid \\
\hline \multirow[t]{2}{*}{5} & Aeon Mall is close to toll road and train. & 0.697 & & Valid \\
\hline & Promotion & & 0.977 & Reliable \\
\hline 1 & $\begin{array}{l}\text { The frequency of Aeon Mall ads is often seen or heard in } \\
\text { the media. }\end{array}$ & 0.913 & & Valid \\
\hline 2 & There is an exciting Aeon Mall advertising. & 0.948 & & Valid \\
\hline 3 & Banner and Aeon Mall poster is placed at strategic location. & 0.966 & & Valid \\
\hline 4 & $\begin{array}{l}\text { The Aeonmall.com website is accessible easily and very } \\
\text { helpful. }\end{array}$ & 0.950 & & Valid \\
\hline \multirow[t]{2}{*}{5} & The ad message is clear. & 0.890 & & Valid \\
\hline & People & & 0.645 & Reliable \\
\hline 1 & The Mall staff is very helpful and empathetic. & 0.630 & & Valid \\
\hline 2 & The mall staff has a good motivation at work. & 0.712 & & Valid \\
\hline 3 & The mall staffs are friendly and courteous. & 0.596 & & Valid \\
\hline 4 & The appearances of Mall staff are clean and neat. & 0.700 & & Valid \\
\hline
\end{tabular}

TRJ Tourism Research Journal, Volume 1(1), 2017 
Marketing Mix Factors that Influence Visitors Choose Aeon Mall as a Shoping Tourism Destination

\begin{tabular}{|c|c|c|c|c|}
\hline & Packaging and Programming & & 0.698 & Reliable \\
\hline 1 & $\begin{array}{l}\text { Aeon Mall organizes special pricing programs, discounts } \\
\text { and vouchers, free samples and attractive prizes to visitors. }\end{array}$ & 0.401 & & Valid \\
\hline 2 & $\begin{array}{l}\text { Aeon Mall holds a program for Privilege Card holders in } \\
\text { the form of auto and motorcycles at the end of the year, as } \\
\text { well as discounts for shopping. }\end{array}$ & 0.529 & & Valid \\
\hline \multirow[t]{2}{*}{3} & There is contest and events at Aeon Mall. & 0.625 & & Valid \\
\hline & Partnership & & 0.858 & Reliable \\
\hline 1 & Aeon Mall has cooperated with certain banks. & 0.624 & & Valid \\
\hline 2 & Aeon Mall has been cooperating with certain tenants. & 0.802 & & Valid \\
\hline \multirow[t]{2}{*}{3} & $\begin{array}{l}\text { Aeon Mall has been cooperating with certain Event } \\
\text { Agency. }\end{array}$ & 0.781 & & Valid \\
\hline & Buying Decision & & 0.816 & Reliable \\
\hline 1 & Aeon Mall has a unique concept. & 0.536 & & Valid \\
\hline 2 & Aeon Mall has a varied tenant. & 0.626 & & Valid \\
\hline 3 & $\begin{array}{l}\text { You visit Aeon Mall because of its attraction as a tourist } \\
\text { shopping area. }\end{array}$ & 0.577 & & Valid \\
\hline 4 & $\begin{array}{l}\text { You visit Aeon Mall because the image / image of Aeon } \\
\text { Mall as a tourist destination shopping area. }\end{array}$ & 0.570 & & Valid \\
\hline 5 & I feel satisfied to visit Aeon Mall. & 0.534 & & Valid \\
\hline 6 & I will make a return visit to Aeon Mall. & 0.511 & & Valid \\
\hline 7 & Aeon Mall has a variety that suits my needs. & 0.541 & & Valid \\
\hline
\end{tabular}

\section{Frequencies}

According to the data, male respondents are around $47 \%$, and women are around $53 \%$. The ages of respondents are $17-37$ years (58\%), 38-58 years (41\%), and $>59$ years $(1 \%)$. Based the job, the respondents who work as entrepreneur is $24 \%$; private employees is $33 \%$; civil servants is $11 \%$; housewives isc $22 \%$, and student is $11 \%$. In the point of salary, the respondents have no income around $7 \%$; < Rp.500.000 is 4\%; and Rp.1000.000-Rp.5000.000 is $10 \%$; Rp.6000.000Rp. 10.000 .000 is $12 \%$; Rp. $11.000 .000-\mathrm{Rp} .15,000,000$ is $18 \%$; Rp. 16.000 .000 Rp. 20.000 .000 is $28 \%$; and $>$ Rp. $20,000,000$ is $22 \%$. The respondents live in South Tangerang (36\%), Tangerang City (33\%), some from Central Jakarta (7\%), West Jakarta ( $8 \%$ ), South Jakarta (10\%), Bogor (3\%), and North Jakarta (4\%).

\section{Mean}

The lowest mean of product sub-variable is 3.56. It's for the adequate parking facilities. The lowest mean of price is 4.50. It's for the statement of an affordable parking ticket. The ticket for parking a car, private is Rp. 3.000,- per hour; car box Rp. 5.000- per hour, and truck or bus Rp. 10,000,- per hour. Motor for the first 2 hours Rp. 2.000,- per hour, and 1 hour later Rp. 1.000,- per 
hour. The ticket is reasonable. The lowest mean of sub-variable place is 3.61. It's for availability of local transportation. According to the observation, the public transportation is needed in the direction to Foresta area. There is only settle bus service. The lowest mean of sub-variable Promotion is 3.64. Aeon Mall advertisement is often seen or heard in media. But the possibility of advertisement on television or in banner in certain area like Bogor or other area is rarely seen. Word of mouth promotion will be the best way to promote things. The lowest mean of sub variable people is 3.80. The staffs are very helpful and empathize towards the visitors. The lowest mean of sub-variable Packaging and Programming is 3.59. Aeon Mall holds a program for holders of Privilage Card in the form of sweepstakes of cars and motorcycles at the end of the year, as well as discounts for shopping. Probably not knowing the end of the privilege card program so that the lottery and discount programs are not felt by most visitors Aeon Mall. The lowest mean of sub-variable Partnership is 3.59. Aeon Mall has cooperated with certain event.

\section{T-Test}

T-test on regression analysis is shown in Table 2.

Table 2. Result T test on Regression Analysis

\begin{tabular}{|c|c|c|c|c|}
\hline \multirow[t]{2}{*}{ Model } & & \multicolumn{3}{|c|}{ Unstandardized Coefficients } \\
\hline & & B & $\mathrm{T}$ & Sig \\
\hline \multirow[t]{8}{*}{1} & (Constant) & 0.923 & 3.917 & 0 \\
\hline & Av_Produk & 0.319 & 6.377 & 0 \\
\hline & Av_Harga & 0.039 & 1.135 & 0.258 \\
\hline & Av_Tempat & 0.038 & 0.844 & 0.399 \\
\hline & Av_Promosi & 0.206 & 5.2 & 0 \\
\hline & Av_Orang & -0.036 & -0.84 & 0.402 \\
\hline & Av_Program & -0.013 & -0.171 & 0.865 \\
\hline & Av_Kerjasama & 0.211 & 2.983 & 0.003 \\
\hline
\end{tabular}

In the table can be seen the equation of multiple linear regression can be formulated equation as follows:

$\mathrm{Y}=(0.923)+(0.319 \mathrm{X} 1)+(0.039 \mathrm{X} 2)+(0.038 \mathrm{X} 3)+(0.206 \mathrm{X} 4)+(-0.036 \mathrm{X} 5)+$ $(-0.013 \mathrm{X} 6)+(0.211 \mathrm{X} 7)$

The multiple linear regression equation is described as follows:

TRJ Tourism Research Journal, Volume 1(1), 2017 
a. Constants 0.923 means that if there is no product factor, price, place, promotion, people, partnership, and packaging and programing, the marketing mix factor to the buying decision of the visitors is equal to 0.923 .

b. Coefficient 0.319 means that any increase in the Product factor of one unit will increase the visitor buying decision 0.319 ..

c. Coefficient 0.039 means that any increase of Price factor of one unit will increase the visitor buying decision 0.039 .

d. Coefficient 0.038 means that every increase Place factor of one unit will increase the visitor buying decision 0,038 .

e. Coefficient 0.206 means that every increase Promotion factor of one unit will increase the visitor buying decision 0206.

f. Coefficient -0.036 means that any increase People factor of one unit will decrease the visitor buying decision 0.036 .

g. Coefficient -0.013 means that every increase Packaging and Programming factor of one unit will decrease the visitor buying decision 0.013 .

h. Coefficient 0.211 means that any increase Partnership factor of one unit will increase the visitor buying decision 0.211 .

\section{Hypothesis Test}

Hypothesis testing is done by using SPSS software 20 version, and hypothetical decision making based on data analysis is done by comparing the significance of $\mathrm{p}$-value probability value and significance level that is $\alpha 5 \%=$ 0.05 with the following conditions:

- If p-value $<0.05$ then the relationship of both variables is significant or Ho rejected and $\mathrm{Ha}$ accepted.

- If p-value $>0.05$ then the relationship between the two variables is not significant or

Ho accepted and Ha rejected.

Table 3. Hypothesis Results

\begin{tabular}{llc}
\hline Hypothesis & $\begin{array}{c}\text { Probability } \\
\text { Significant }\end{array}$ & Results \\
& p-value & H1 Accepted \\
H1: There is a positive and significant influence between & 0.000 & \\
the Product and the decision of the visitor choosing a \\
shopping tour at Aeon Mall
\end{tabular}

TRJ Tourism Research Journal, Volume 1(1), 2017 
shopping tour at Aeon Mall

H4: There is a positive and significant influence between $0.000 \quad$ H4 Accepted the Promotion and the decision of the visitor choosing a shopping tour at Aeon Mall

H5: There is a positive and significant influence between the People and the decision of the visitor choosing a shopping tour at Aeon Mall

H6: There is a positive and significant influence between the Packaging and Programming and the decision of the visitor choosing a shopping tour at Aeon Mall

H7: There is a positive and significant influence between the Partnership and the decision of the visitor choosing a shopping tour at Aeon Mall

$0.402 \quad$ H5 Rejected

$0.865 \quad$ H6 Rejected

0.003

H7 Accepted

\section{F-Test}

Based on the result f-test, in column (Sig) or score probability value significance with score 0,000 or below 0,05 . It means independent variable that consists of product, price, place, promotion; person, partnership, packing and programming have significant influence positively to select visitors. F-test result is described in Table 4.

Table 4. The Results of f-Test

\begin{tabular}{llc}
\hline Model & & Sig. \\
\hline 1 & Regression & $.000^{\mathrm{b}}$ \\
& Residual & \\
\cline { 2 - 3 } & Total & \\
\hline
\end{tabular}

\section{Hypothesis Testing}

Hypothesis testing is done by using SPSS software 20 version, and hypothetical decision making based on data analysis is done by comparing the significance of $\mathrm{p}$-value probability value and significance level that is $\alpha 5 \%=$ 0.05 with the following conditions:

a. If $\mathrm{p}$-value $<0.05$ then the relationship of both variables is significant or $\mathrm{H} 0$ rejected and $\mathrm{Ha}$ accepted.

b. If $p$-value $>0.05$ then the relationship between the two variables is not significant or $\mathrm{HO}$ accepted and $\mathrm{Ha}$ rejected.

TRJ Tourism Research Journal, Volume 1(1), 2017 
Hypothesis results can be seen in Table 5.

Table 5. Hypothesis Results

\begin{tabular}{lll}
\hline Hypothesis & $\begin{array}{l}\text { Probability } \\
\text { Significant } \\
\text { p-value }\end{array}$ & Results \\
& & \\
& & H8 Accepted \\
$\begin{array}{l}\text { M8 : There is a positive and significant Influence between } \\
\text { shopping Destination at Aeon Mall }\end{array}$ & 0.000 & \\
\hline
\end{tabular}

Based on the results of data for Marketing Mix variables p-value value $0.000<0.05$ indicates that the hypothesis accepted. It means there is a positive and significant influence between the Marketing Mix with the decision of visitors to choose shopping destination in Aeon.

\section{Coefficient Determination}

The result of coefficient value on regression analysis is described in Table 6.

Table 6. Coefficient Value on Regression Analysis

\begin{tabular}{llllll}
\hline Model & $\mathrm{R}$ & $\mathrm{R}$ Square & $\begin{array}{l}\text { Adjusted } \\
\text { Square }\end{array}$ & $\mathrm{R}$ & $\begin{array}{l}\text { Std. Error of the } \\
\text { Estimate }\end{array}$ \\
\hline 1 & $0.821^{\mathrm{a}}$ & 0.673 & .662 & .26828 \\
\hline
\end{tabular}

Based on the table, it shows that the correlation coefficient value of 0.821 is approaching the value of 1 . It means that product, price, place, promotion, partnership, packaging and programming have a positive and strong impact to buying decision.

Coefficient determination of 0.673 or $67.3 \%$ means that product; price, place, promotion, people, partnership, and packaging and programs influence buying decision $67.3 \%$ and $32.7 \%$ was caused by other factors.

From the marketing mix, $\mathrm{X}$ variables such as product, price, place, promotion, person, packaging and program, and partnership has positive and significant variables are product, promotion, and partnership.

Variable Y from the visitor decisions choose the lowest mean of 3.76 ie you visit Aeon Mall because the image / image Aeon Mall as a shopping destination tourism area. Possible visitors assume Aeon Mall is just a shopping place in general like other malls that provide various facilities and lifestyle for 
visitors. Although some tenants are from Japan, and available 25 newly opened tenants in Indonesia, Aeon Mall can cooperate with other unopened international tenants in South Tangerang, so visitors are increasingly interested in doing shopping.

Coefficient value on regression analysis, correlation coefficient value $(\mathrm{R})$ 0.821 which is approaching number 1 , which means simultaneously or together has a positive influence relationship or strong positive linearity correlation to free variable that is, product, price, place, promotion, People, packaging and programs and partnership.

\section{E. Conclusion}

According to the study, it's concluded that there is a positive and significant influence between the Product and the decision of the visitor choosing a shopping tour at Aeon Mall; There isn't a positive and significant influence between the Price and the decision of the visitor choosing a shopping tour at Aeon Mall; There isn't a positive and significant influence between the Place and the decision of the visitor choosing a shopping tour at Aeon Mall; There is a positive and significant influence between the Promotion and the decision of the visitor choosing a shopping tour at Aeon Mall; There isn't a positive and significant influence between the People and the decision of the visitor choosing a shopping tour at Aeon Mall; There isn't a positive and significant influence between the Packaging and Programming and the decision of the visitor choosing a shopping tour at Aeon Mall; There is a positive and significant influence between the Partnership and the decision of the visitor choosing a shopping tour at Aeon Mall; There is a positive and significant Influence between Marketing Mix with the decision of visitors to choose shopping Destination at Aeon Mall.

Product, price, place, promotion; person, partnership, packing and programming have a positive and significant impact to select visitors. Product, price, place, promotion, people, partnership, and packaging and programs influence buying decision; the mall must provide adequate parking facilities. The mall can settle additional parking space, on every weekend and holidays. The mall can expand the parking area by buying a field around the area and build a parking area or for now the mall can add security outside the parking area of the mall area. Next, the ticket for parking a car, private is Rp. 3.000,- per hour; car box Rp. 5.000- per hour, and truck or bus Rp. 10,000,- per hour. Motor for the first 2 hours Rp. 2.000,- per hour, and 1 hour later Rp. 1.000,- per hour. The ticket is reasonable. It's recommended that the mall can add other facilities such as CCTV, valet, and the addition of lights in some corners of minimal lighting, In addition, the addition of parking counters in and out, because very long car queuing. The public roads must be managed so the motorists will be easy to pass through the road. After that, the mall must provide local transportation.

TRJ Tourism Research Journal, Volume 1(1), 2017 
According to the observation, the public transportation is needed in the direction to Foresta area. There is only settle bus service. There will be better if the mall can optimize the service of a free bus facility. A bus service that is provided by the Aeon Mall is often late. So most visitors are reluctant to use this facility. Visitors must wait longer than the schedule already announced by the mall. Therefore, the management must coordinate with the bus service or can be monitored so that the facility can be useful efficiently. Then, the Aeon Mall advertisement must be easy to be seen or heard in media. But the possibility of advertisement on television or in banner in certain area like Bogor or other area is rarely seen. Word of mouth promotion will be the best way to promote things. The mall can increase the frequency of advertising on television, because surely everyone has television as one of the entertainment at home and the spread of advertisements will be widespread reachable people outside the area, although the influence of an influential promotion is electronic word of mouth but at a certain age or the previous generation. Actually, the staff has been very helpful and empathizes towards the visitors.

Even though, it's recommended that there is a training to increase the knowledge and expertise to the staff every month. In the case of improving the number of visitor, Aeon Mall holds a program for holders of Privilage Card in the form of sweepstakes of cars and motorcycles at the end of the year, as well as discounts for shopping. Probably not knowing the end of the privilege card program so that the lottery and discount programs are not felt by most visitors Aeon Mall. Therefore, the mall needs to improve the news about the program, so that more and more visitors who participate in the privilege card program. Finally, Aeon Mall must improve cooperated with certain event. The mall may hold cultural-related collaborations, special events based on traditional culture with Japanese cultural collaboration. For example Jaipong dance with traditional Japanese music arrangement.

\section{F. Acknowlegement}

1. Mr. Himawan Brahmantyo, as the Mentor Advisor and my lecturer who is always patient in providing guidance and direction to the author.

2. Mr. Adinoto Nursiana, as the Mentor Advisor who is always patient in providing guidance and direction to the author.

3. My parents, Mr. Chandra Mulyono and Mrs. Tatti Hadinoto S.Pd, as well as my sister Octavine Christie S.Tr.Par who have given many encouragement both materially and spiritually 


\section{REFERENCES}

Anjar H.K. (2011). Pengarub Harga, Lokasi dan Fasilitas Terhadap Keputusan Berkunjung Wisatawan di Objek Wisata Dampo Awang Beach Rembang. Universitas Negeri Semarang.

Appiah-Adu, K., Fyall, A. and Singh, S. (2000). Marketing culture and customer retention in the tourism industry. The Service Industries Journal, Vol. 20 No. 2,pp. 95-113.

BAPEDA Kota Tangerang Selatan “Kota Tangerang Selatan dalam Angka 2013”. Tangerang Selatan : BPS Kota Tangerang Selatan,2013.

Cooper, D.R., and Pamela S. S.( 2011). Business Research Method's. New York:McGraw Hill.

Hidayat, H.D., and Febby, W. (2014). Analisis Pengaruh Lokasi, Promosi dan Keragaman Tenant terhadap Keputusan Berbelanja di Mal Gandaria City. Jurnal Ilmiah Prodi Manajemen Universitas Pamulang.

Engel, J.F., Blackwell, R.D., and Miniard, P.W.(1995). Perilaku Konsumen.Terjemahan: Budiyanto, Binarupa Aksara, Jakarta.

Ezeh, C. and Harris, L.C. (2007). Servicescape research: a review and a research agenda. Marketing Review, January.

Fandy, T. (2000). Manajemen Jasa. Yogyakarta :Penerbit Andi.

Fyall, A., et al . (2008). Managing Visitor Attraction. Second Edition. USA: Butterworth-Heinemann.

Ghozali, I. (2007). Analisis Aplikasi Multivariat denga Program SPSS. Semarang: Badan Penerbit Universitas Dipenegoro.

Ghanimata, F. (2012). Analisis Pengarub Harga, Kualitas Produk, Dan Lokasi Terhadap Keputusan Pembelian (Studi pada Pembeli Produk Bandeng Juwana Elrina Semarang). Skripsi. Semarang: Fakultas Ekonomika dan Bisnis, Universitas Diponegoro.

Hair, J.F., Black, W.C., Babin, B.J., Anderson, R.E., Tatham, R.L. (2006). Multivariate Data Analysis, 6 Ed., New Jersey : Prentice Hall

International Council of Shopping Center. (1999). ICSC Shopping Center Definitions: Basic Configurations and Types. Tersedia: http://www.icsc.org/

Kadek D.F. (2011). Reformulasi Strategi Pemasaran Untuk Meningkatkan Occupancy Room Rate Di Hotel Four Seasons Resort Jimbaran Bali. Tesis Magister Manajemen. Universitas Udayana.

Kenesei, Z. dan Sarah T. (2003). The Use of Price in the Purchase Decision. Journal of Empirical Generalisations in Marketing Science. (http://www.empgens.com)

Kotler, P., Tohn, T.B., and James, C.M. (2010). Marketing for Hospitality and Tourism. New Jersey : Pearson.

Lubis, A.F. (2012). Pasar modal. Jakarta: Fakultas Ekonomi Universitas Indonesia.

TRJ Tourism Research Journal, Volume 1(1), 2017 
Malcolm McD., Pennie, F., Adrian, P. (2001). Marketing Plans for Services: A Complete Guide, 3rd Edition._ New Jersey:John Wiley \& Sons, Inc.

Marpaung, H. (2002) Pengetahuan Kepariwisataan. Bandung : Alfabeta.

Munandar, A.U. (2001). Psikologi Industri dan Organisasi. Jakarta:Penerbit Universitas Indonesia (UI-Press).

Morrison, A.J. (2002). Marketing Strategic Alliances: The Small Hotel Firm. International Journal of Contemporary Hospitality Management. Vol 6:3. USA: MCB University Limited.

Morrison, A. (2002). Hospitality and Travel Marketing. Third Edition. Australia: Delmar Thompson Learning.

Narda, N. P., Andi T. H., Mukeri W .(2016). Efektifitas Atmoshper dan Event Marketing terhadap Keputusan Pembelian yang Dimediasi oleh Minat Beli pada Konsumen Tembi Rumah Budaya Yogyakarta. Jurusan Manajemen Fakultas Ekonomika dan Bisnis Universitas Pandanaran.

Pacione, M., (2005). Urban Geography: a Global Perspective (2nd Edition). London: Routledge.

Rafiuddin. (2013). Sungai Pangkajene sebagai Objek dan Daya Tarik Wisata di Kabupaten Pangkajene dan Kepulauan. Jakarta: Sekolah Tinggi Pariwisata Trisakti Program Pascasarjana.

Richard, G. (2001). Cultural Attractions and European Tourism. :CABI.

Riza, A. (2013). Faktor-Faktor yang Mempengarubi Wisatawan Memilih Kasus Museum Goedang Ransoem-Sawahlunto. Jakarta: Sekolah Tinggi Pariwisata Trisakti Program Pascasarjana.

Siburian, C.K. (2013). Pengaruh Produk, Harga, Lokasi, Dan, Promosi Wisata Terhadap Minat Berkunjung Kembali Ke Tempat Wisata Draco Waterpark Hermes Medan. Jurnal. Medan: Fakultas Ekonomi Universitas Sumatera Utara.

Sherly P. and Mahaendra Y.I.N. (2013). Faktor-faktor yang Mempengaruhi Keputusan Wisatawan Domestik Berbelanja di Pasar Oleh-oleh Modern ( Studi Kasus di Kota Denpasar). E-Jurnal Ekonomi Pembangunan Universitas Udayana Volume. 2, No.5.

Shopping mall and shopping center studies. (2009). Eastern Connecticut State University.

Sudana. (2005). Strategi Pemasaran Industri Cafe-Cafe di Sentra Parivisata Pantai Kedonganan Kabupaten Badung. Tesis Magister Manajemen. Universitas Udayana.

Susilowati. (2002). Strategi Pemasaran Yang Tepat Diterapkan Oleh Hotel Phoenix Yogyakarta. Tesis Magister Manajemen. Universitas Udayana.

Swasta, B., and Hani, H. (2000). Manajemen Pemasaran Analisa Perilaku Konsumen. Yogyakarta: BPFE.

Welli, B.K. (2012). Pengaruh Faktor Bauran Promosi terhadap Ekuitas Merek TerasKota Entertainment Center BSD-Tangerang Selatan. Jakarta: Sekolah Tinggi Pariwisata Trisakti Program Pascasarjana.

TRJ Tourism Research Journal, Volume 1(1), 2017 
William, J.S., Michael, J.Etzel., \& Bruce, J.W. (1994). Dasar-dasar Manajemen Pemasaran, cetakan 1. Bandung: Penerbit Mandar Maju.

http://properti.kompas.com/read/2015/09/15/104234021/BSD.Semakin.Men curi.Hati.Investor

http://tangerangnews.com/bisnis/read/14810/AEON-Mall-Resmi-Buka-diTangerang

https://wolipop.detik.com/read/2015/04/01/143340/2875946/1141/aeonmall-pusat-perbelanjaan-bernuansa-jepang-segera-hadir-di-indonesia

http://tangerangnews.com/bisnis/read/17400/AEON-Mall-Tahun-Pertamanya https://wolipop.detik.com/read/2015/04/02/171509/2877271/1141/mengena l-lebih-dekat-aeon-mall-pusat-perbelanjaan-bernuansa-jepang.

http://marketeers.com/alphonzus-widjaja-otak-di-balik-kesuksesan-aeon-mall$\underline{\mathrm{bsd} /}$

http://properti.bisnis.com/read/20150826/276/465882/amsl-buka-kerja-samabangun-20-mal-aeon

www.aeonmall.com

TRJ Tourism Research Journal, Volume 1(1), 2017 